УДК 371.134: 811.1/.2 + 81'24 (045)

Режим доступу до журналу: http://www.journal.iitta.gov.ua

Данилюк Сергій Семенович, кандидат філологічних наук, доцент, доцент кафедри практики англійської мови Навчально-наукового інституту іноземних мов Черкаського національного університету імені Богдана Хмельницького, м. Черкаси, e-mail: sedan@bigmir.net

\title{
ПЕРЕВАГИ І НЕДОЛІКИ ВИКОРИСТАННЯ ІНФОРМАЦЙНО- КОМП'ЮТЕРНИХ ТЕХНОЛОГІЙ У ПРОЦЕСІ ФОРМУВАННЯ ПРОФЕСІЙНОЇ КОМПЕТЕНТНОСТІ МАЙБУТНІХ ФІЛОЛОГІВ
}

\begin{abstract}
Анотація
Актуальність статті полягає у вивченні впливу комп’ютерних технологій на процес комп'ютеризації освіти, котрий супроводжується внесенням коректив у зміст технологій навчання внаслідок суттєвих змін у педагогічній теорії і практиці навчально-виховного процесу. Метою статті є висвітлення переваг і недоліків використання інформаційно-комп'ютерних технологій у процесі формування професійної компетентності майбутніх філологів. У статті визначено ролі й завдання викладача як керівника навчального процесу, а також чинники, котрі впливають на якість освіти. У статті наголошено на перспективі розроблення комплексу завдань із використанням комп'ютерної техніки для формування професійної компетентності майбутніх філологів у ВНЗ.
\end{abstract}

Ключові слова: інформаційно-комп'ютерні технології, навчальний процес, Інтернет, професійна компетентність фахівця.

Постановка проблеми. Сучасний період розвитку суспільства характеризується суттєвим впливом комп'ютерних технологій, які проникають в усі сфери людської діяльності, забезпечують поширення інформаційних потоків у суспільстві, утворюючи глобальний інформаційний простір. Невід’ємною і важливою частиною становлення нової системи освіти, орієнтованої на входження до світового інформаційно-освітнього простору, є процес комп’ютеризації освіти. Цей процес супроводжується суттєвими змінами в педагогічній теорії і практиці навчальновиховного процесу, що пов'язані з внесенням коректив у зміст технологій навчання, 
котрі мають бути адекватними сучасним технічним можливостям, i сприяти гармонійному входженню людей в інформаційне суспільство.

Аналіз досліджень і публікацій. Сутність процесу інформатизації, який набув значного поширення в царині освіти і значною мірою впливає на динаміку розвитку сучасного суспільства, розкрито в роботах А. А. Вербицького [4], Т. П. Вороніної [5], К. К. Коліна [9], П. І. Образцової [12], С. С. Полат [13], Д. Белл [3], А. Тоффлера [15] й ін.).

В умовах модернізації й інформатизації системи освіти інформаційнокомп’ютерні технології (далі ІКТ) слід розглядати як засіб формування професійної компетентності студентів.

Проведений аналіз наукової літератури свідчить про те, що в педагогіці ще недостатньо повно розкрито потенційні можливості використання ІКТ як засобу формування професійної компетентності фахівця. Безперечну цінність для визначення сутності і змісту ІКТ-компетентності становлять роботи В. А. Адольфа [1], О. Б. Зайцевої [6], І. Ф. Ісаєва [7], М. Б. Лебедєвої [10], А. В. Хуторського [14] й ін. Аналіз теоретичних досліджень і практичного досвіду сучасної педагогічної діяльності показує, що, незважаючи на пильну увагу до підвищення якості професійної підготовки студентів, проблема використання ІКТ як засобу формування професійної компетентності фахівців залишається недостатньо вивченою.

Мета статті. За мету статті поставлено завдання висвітлити переваги й недоліки використання інформаційно-комп'ютерних технологій $\quad$ у процесі формування професійної компетентності майбутніх філологів.

Виклад матеріалу. Використання інформаційних комп'ютерних і мультимедіятехнологій у царині освіти радикально змінює наявну систему навчання. Організація навчального процесу стає індивідуалізованішою, оскільки широке застосування аналітичних, практичних й експериментальних принципів навчання дозволяє орієнтувати його на кожного майбутнього філолога. Роль викладача в навчальному процесі й вимоги до педагога при цьому змінюються. Викладач перестає бути єдиним джерелом знання, стаючи керівником і помічником майбутніх філологів в освітньому процесі. У нових умовах викладач, окрім досконалого знання свого предмета, має забезпечити педагогічне керівництво і контроль результатів навчання, заохочуючи майбутніх філологів до самоосвіти, забезпечуючи їм умови мотивації навчання й націлюючи їх 
на самостійний пошук знань, а також виробляючи в них прагнення до критичного аналізу навчального процесу і його результатів [7, с. 82].

Завдання викладача як керівника навчального процесу в цілому такі:

1) формування навчальних груп;

2) загальне керівництво процесом навчання;

3) планування і проведення практичних занять;

4) планування і розподіл ролей і обов’язків майбутніх філологів у ділових іграх, дискусіях, навчальних проектах тощо;

5) виконання «фонових» функцій контролю й допомоги майбутнім філологам у їхній самостійній роботі;

6) контроль і заохочення активної участі майбутніх філологів у навчальному процесі;

7) координація роботи й допомога майбутнім філологам;

8) встановлення інтерактивних зв'язків й організація взаємодії між майбутніми філологами і зовнішнім інформаційним середовищем у процесі навчання;

9) стимулювання спілкування майбутніх філологів.

Викладач як наставник майбутніх філологів, які потрапили у складну ситуацію, виступає в ролі:

1) «ініціатора», який може допомогти організувати навчальну діяльність і сприяти процесу навчання у групі;

2) «модератора (посередника)» в дискусії, якщо обговорення заходить у глухий кут, або в майбутніх філологів, які дискутують, вичерпуються аргументи. Це не означає, що викладач обов' язково має пропонувати їм готовий розв'язок, але він може підказати можливі шляхи подолання складнощів, які виникають;

3) «критичного наставника», який допомагає вчитися, приймати рішення в навчальних ситуаціях, котрі ускладнюються. Наприклад, викладач допомагає не лише збирати інформацію з різних джерел, а й структурувати іï, залишаючи лише необхідні дані;

4) «радника», який пояснює, як учитися і застосовувати отриманий досвід на практиці;

5) «експерта», який може допомогти порадою у складній ситуації, надавши додаткову інформацію з необхідного питання; 
6) «натхненника», який у разі зниження мотивації, викликаному депресією або виникненням складнощів, підтримує майбутніх філологів, орієнтуючи їх на позитивний результат. Часто під час навчання виникає морально-психологічна втома від навчальних завдань, що слід ураховувати викладачеві, який має вчасно надихнути зневірених майбутніх філологів, допомагаючи їм подолати цей стан.

На якість освіти впливають:

1) соціальний контакт і людські взаємини майбутніх філологів (з членами родини, іншими колегами, викладачами, друзями), тобто співтовариства, у яких відбувається отримання знань, практичного досвіду, спілкування та розвиток навичок співробітництва;

2) об’єкти навчання, тобто навчальні матеріали (книги, відео-, аудіозаписи, ресурси Інтернету або мультимедія на CD / DVD-дисках), фізичні і штучні об'єкти, а також інші навчальні ресурси;

3) навчальне середовище, у якому відбувається навчальний процес: його структура, умови проведення, а також бібліотеки, центри мультимедійних ресурсів, комп'ютерні лабораторії;

4) навколишнє середовище [2, с. 21].

Використання мультимедія дозволяє надати майбутнім філологам більше можливостей для самостійної і незалежної роботи, а також гнучко варіювати програму навчальної діяльності. Майбутнім філологам надається можливість самостійного пошуку потрібних їм знань, вибору індивідуальних стратегій навчання, які дозволяють кожному з них стати активним учасником навчального процесу і критично підійти до наданої навчальної інформації. Розвивається потреба ділитися отриманими знаннями.

3 точки зору організації навчального процесу, інтеграція засобів мультимедія у викладанні й навчанні вимагає аналітичного, практичного й експериментаторського підходів, сконцентрованих як на майбутніх філологах, так і на викладачах, координаторах навчального процесу із застосування інформаційних комп'ютерних технологій та інших педагогічних працівниках.

Досі ми говорили про ті переваги, які вносить у навчальний процес застосування комп'ютера. Проте з його використанням пов’язані й певні недоліки, й про них не слід забувати.

Необхідно чітко розрізняти недоліки, зумовлені: 
1) недосвідченістю розробників тієї чи іншої комп’ютерної навчальної системи, які створюють програми без урахування дидактичних принципів;

2) неповною реалізацією потенційних можливостей комп'ютера;

3) самою природою комп’ютера як деякої технічної системи. Усі ці недоліки, у принципі, можна усунути.

Більш істотними є причини невдалого використання комп'ютерів, коли не враховуються обмеження, які визначаються самою природою цих пристроїв. Наприклад, не береться до уваги можливість збоїв або відсутність таких аспектів взаємодії, як особисте спілкування викладача i майбутніх філологів. Під час оцінювання ролі комп'ютера у здійсненні реформи вищої школи слід, насамперед, враховувати, які навчальні функції доцільно йому передати, пам’ятаючи при цьому, що комп'ютер є лише засобом, а не суб'єктом навчальної діяльності, що він є не більше, ніж помічником педагогу, а не його заміною [11, с. 15].

Використання сучасних засобів інформаційних технологій у всіх формах навчання може призвести й до низки негативних наслідків. Зокрема, найчастіше однією 3 переваг навчання за допомогою засобів інформатизації називають індивідуалізацію навчання. Однак, поряд з очевидними перевагами використання інформаційних технологій у навчальному процесі, наявна також і велика кількість суттєвих недоліків, пов’язаних із тотальною індивідуалізацією навчання [8]. Нерідко як аргумент проти використання комп’ютера наводять твердження, що він порушує живе спілкування майбутніх філологів із викладачем. Цей аргумент не $\epsilon$ переконливим. Живе спілкування педагога 3 майбутніми філологами в умовах групового навчання має низку істотних недоліків. Зазначимо, що викладач щоразу продуктивно спілкується не з усією групою, а з окремими іï представниками. А решта майбутніх філологів не беруть участі в роботі на занятті: одним це не цікаво, іншим $\mathrm{i}$ так все зрозуміло, а треті просто заглиблені у свої проблеми, які не мають нічого спільного з тими, що розглядаються на занятті. Перекладаючи частину навчальних функцій на комп’ютер, викладач може більше спілкуватись з майбутніми філологами, займаючись не стільки їх навчанням, скільки вихованням [11, с. 16]. Така індивідуалізація зводить до мінімуму обмежене в навчальному процесі живе спілкування викладачів і майбутніх філологів, а також майбутніх філологів між собою, пропонуючи їм спілкування у вигляді «діалогу 3 комп’ютером». Це 
призводить до того, що майбутні філологи, які активно користуються живим мовленням, надовго замовкають під час роботи 3 інформаційними технологіями. Мова як орган об'єктивізації мислення людини виявляється вимкненою, знерухомленою упродовж багатьох років навчання. Майбутні філологи не отримують достатньої практики діалогічного спілкування, формування та формулювання думки професійною мовою.

Іншим істотним недоліком повсюдного використання інформаційних технологій у галузі освіти є згортання соціальних контактів, скорочення практики соціальної взаємодії і спілкування, індивідуалізм. Найбільшу складність становить перехід від інформації, котра циркулює в системі навчання, до самостійних професійних дій, інакше кажучи, від знакової системи як форми представлення знання на сторінках підручника, екрані дисплея тощо до системи практичних дій, котрі мають принципово іншу логіку, ніж логіка організації системи знаків.

Певні складнощі й негативні моменти можуть виникнути в результаті застосування сучасних інформаційних технологій, що надають викладачам i майбутнім філологам значну свободу в пошуку і використанні інформації. Доволі часто деякі педагоги й майбутні філологи нездатні скористатися тією свободою, яку надають їм сучасні інформаційні технології. Заплутані і складні способи надання інформації можуть стати причиною відволікання майбутніх філологів від виучуваного матеріалу внаслідок різних невідповідностей. До того ж, нелінійна структура інформації спонукає майбутніх філологів активувати запропоновані посилання, що, за обставин невмілого використання пропонованої інформації, може відволікти увагу майбутніх філологів від основного русла викладу навчального матеріалу.

Колосальні обсяги інформації, котрі подаються такими інформаційними засобами, як електронні довідники, енциклопедії й Інтернет-портали також можуть відволікати увагу майбутніх філологів у процесі навчання. Більше того, короткочасна пам’ять людини має доволі обмежені можливості. Як правило, звичайна людина здатна впевнено одночасно пам'ятати й оперувати лише сімома різними можливими мнемоодиницями. Коли майбутні філологи одночасно демонструють інформацію різних типів, може виникнути ситуація, у якій вони відволікаються від одних типів інформації, аби зафіксувати в пам’яті інші, пропускаючи важливу інформацію. 
Використання інформаційних ресурсів, які опубліковані в мережі Інтернет, часто призводить до негативних наслідків. Найчастіше за використання інформаційних технологій спрацьовує властивий усьому живому принцип економії зусиль: запозичені з мережі Інтернет готові проекти, реферати, доповіді стали нині поширеним і звичним явищем, що не сприяє підвищенню ефективності навчання i виховання майбутніх філологів.

Певну небезпеку становить зовнішне поверхневе використання інформаційних технологій й інформаційних ресурсів для виконання малозначущих у загальноосвітньому плані групових й індивідуальних проектів.

Інформаційні технології можуть стати не лише потужним засобом становлення i розвитку майбутніх філологів (як особистості, суб'єкта пізнання, практичної діяльності, спілкування, самосвідомості), а й, навпаки, сприяти формуванню шаблонного мислення, формального і безініціативного ставлення до діяльності тощо.

Не можна також забувати про те, що надмірне і невиправдане використання більшості засобів інформатизації негативно відбивається на стані здоров'я учасників навчального процесу [8].

Тому для забезпечення ефективного i грунтовного засвоєння майбутніми філологами необхідної навчальної інформації, викладачеві слід використовувати різні методи індивідуального навчання, які дозволили б кожному стати активним учасником процесу навчання і критично підходити до виучуваного матеріалу.

Висновки. Проникнення сучасних інформаційних технологій у царину освіти дозволяє педагогам якісно змінити зміст, методи й організаційні форми навчання. Основною метою цих технологій в освіті є посилення інтелектуальних можливостей студентів в інформаційному суспільстві, а також гуманізація, індивідуалізація, інтенсифікація процесу навчання і підвищення якості навчання на всіх ступенях навчального процесу.

Всесвітня мережа Інтернет надає студентам доступ до різних банків інформації і послуг, наприклад, різноманітних довідникових систем, а також уможливлює обмін інформацією зі своїми кореспондентами в режимі діалогу. Використання мережі Інтернет, а також різноманітних телекомунікаційних засобів значною мірою сприяє опануванню студентами-філологами виучуваними мовами. 
Отже, переваги використання інформаційно-комп'ютерних технологій у процесі формування професійної компетентності майбутніх філологів визначаються: 1) індивідуалізацією навчального процесу; 2) можливостями для самостійної i незалежної роботи; 3) гнучким варіюванням програми навчальної діяльності. У свою чергу, недоліки використання зазначених технологій у навчальному процесі характеризуються: 1) невдалим використанням комп'ютерів, коли не враховуються обмеження, котрі визначаються самою природою цих пристроїв; 2) зведенням до мінімуму обмеженого в навчальному процесі живого спілкування викладачів і майбутніх філологів, а також майбутніх філологів між собою; 3) згортанням соціальних контактів, скороченням практики соціальної взаємодії та спілкування, індивідуалізмом; 4) сприянням формуванню шаблонного мислення, формального і безініціативного ставлення до діяльності тощо; 5) на стані здоров’я учасників навчального процесу.

Перспективи подальших пошуків у напрямку дослідження. Виявлення й опис переваг і недоліків використання інформаційно-комп'ютерних технологій у навчальному процесі має перспективу в плані розроблення комплексу завдань із використанням комп’ютерної техніки для формування професійної компетентності майбутніх філологів у ВНЗ.

\section{Список використаних джерел}

1. Адольф B. A. Выявление уровня информационной компетентности выпускников общеобразовательных учреждений / В. А. Адольф, И. Ю. Степанова, О. А. Гумеров // Информатика и образование. - 2007. - № 5. - С. 116-119.

2. Андресен Б. Мультимедиа в образовании / Б. Андресен, К. Бринк. - М. : Дрофа, 2007. - 224 с.

3. Белл Д. Грядущее постиндустриальное общество. Опыт социального прогнозирования / Д. Белл. - М. : Академия, 2004. - 788 с.

4. Вербицкий A. А. Активное обучение в высшей школе: Контекстный подход / А. А. Вербицкий. - М. : Высшая школа, 1991. - 207 с.

5. Воронина T. П. Информационное общество: сущность, черты, проблемы /Т. П. Воронина. - М. : Логос, 1998. - 112 с.

6. Зайщева $C$. $A$. Современные информационные технологии в образовании [Электронный ресурс] / С. А. Зайцева, В. В. Иванов. - Режим доступа : http://sgpu2004.narod.ru/infotek/infotek2.htm (06.11.11). - Заглавие с экрана. 
7. Исаев И. Ф. Профессионально-педагогическая культура преподавателя / И. Ф. Исаев. - М. : Издательский центр «Академия», 2004. - 207 с.

8. Использование информационных и коммуникационных технологий в общем среднем образовании [Электронный ресурс]. - Режим доступа : http://ido.rudn.ru/nfpk/ikt/ikt1.html. - Заглавие с экрана.

9. Колин К. К. Информационное общество / К. К. Колин. - Челябинск : ЧГАКИ, 2010. - 27 с.

10. Лебедева M. Б. Как готовить студентов к использованию информационных и коммуникационных технологий в профессиональной педагогической деятельности? / М. Б. Лебедева // Информационные технологии в науке, образовании, искусстве. - С.-Пб. : Изд-во РГПУ им. А. И. Герцена, 2005. C. 132-136.

11. Машбии Е. И. Психолого-педагогические проблемы компьютеризации обучения / Е. И. Машбиц. - М. : Педагогика, 1988. - 192 с.

12. Образиов П. И. Информационно-технологическое обеспечение учебного процесса в вузе / П. И. Образцов // Высшее образование в России. - 2001. - № 6. C. $46-50$.

13. Полат E. С. Новые педагогические и информационные технологии в системе образования / Е. С. Полат. - М. : Издательский центр «Академия», 2003. $272 \mathrm{c}$.

14. Хуторской А. В. Ключевые компетенции как компонент личностноориентированной парадигмы образования / А. В. Хуторской // Народное образование. 2003. - № 2. - С. 58-64.

15. Toffler A. The Third Wave / A. Toffler. - New York : Bantam Books, 1990. $540 \mathrm{p}$.

ПРЕИМУЩЕСТВА И НЕДОСТАТКИ ИСПОЛЬЗОВАНИЯ ИНФОРМАЦИОННО-КОМПЬЮТЕРНЫХ ТЕХНОЛОГИЙ В ПРОЦЕССЕ ФОРМИРОВАНИЯ ПРОФЕССИОНАЛЬНОЙ КОМПЕТЕНТНОСТИ БУДУЩИХ ФИЛОЛОГОВ

Данилюк Сергей Семенович, кандидат филологических наук, доцент кафедры практики английского языка Учебно-научного института иностранных языков 
Черкасского национального университета имени Богдана Хмельницкого, г. Черкассы, e-mail: sedan@bigmir.net

\section{Аннотация}

Актуальность статьи заключается в изучении влияния компьютерных технологий на процесс компьютеризации образования, который сопровождается внесением корректив в содержание технологий обучения вследствие существенных изменений в педагогической теории и практике учебно-воспитательного процесса. Целью статьи является освещение преимуществ и недостатков использования информационнокомпьютерных технологий в процессе формирования профессиональной компетентности будущих филологов. В статье определены роли и задания преподавателя как руководителя учебного процесса, а также факторы, влияющие на качество образования. В статье обозначены перспективы разработки комплекса заданий с использованием компьютерной техники для формирования профессиональной компетентности будущих филологов в вузе.

Ключевые слова: информационно-компьютерные технологии, учебный процесс, Интернет, профессиональная компетентность специалиста.

\section{ADVANTAGES AND DISADVANTAGES OF USING INFORMATION-AND- COMPUTER TECHNOLOGIES IN THE PROCESS OF FORMATION OF FUTURE PHILOLOGISTS' PROFESSIONAL COMPETENCE}

Serhiy S. Danylyuk, Ph.D. in Linguistics, Associate Professor of Conversational English Department, Educational-Scientific Institute of Foreign Languages, Cherkasy Bohdan Khmelnytsky National University, Cherkasy, e-mail: sedan@bigmir.net

\section{Resume}

The topicality of the article is in observing the influence of computer technologies on the process of computerization of education, which is characterized by making corrections in the content of teaching technologies, taking into account important changes in theory and practice of teaching in the training-educational process. The aim of the article is highlighting of advantages and disadvantages of using information-and-computer technologies in the process of formation of future philologists' professional competence. Roles and tasks of a lecturer as a head of the educational process as well as factors, which characterize the quality of education are defined in the article. Perspectives of working out a 
complex of tasks which presuppose using computer appliances to form future philologists' professional competence in higher educational establishments are suggested in the article.

Keywords: information-and-computer technology, educational process, Internet, professional competence of a specialist.

Матеріал надійшов до редакції 05.03.2012 p 